POLLACK PERIODICA

An International Journal for Engineering and Information Sciences

DOI: $10.1556 / 606.2016 .11 .1 .4$

Vol. 11, No. 1, pp. 35-41 (2016)

www.akademiai.com

\title{
ASSESSMENT AND DESIGN OF THE FLOOD PROTECTION MEASURES IN THE DISTRICT OF LEVICE (SLOVAKIA)
}

\author{
${ }^{1}$ Stanislav KELČÍK, ${ }^{2}$ Tatiana PINDJAKOVÁ, ${ }^{3}$ Andrej ŠOLTÉSZ \\ Department of Hydraulic Engineering, Faculty of Civil Engineering, \\ Slovak University of Technology, Radlinského 11, 81368 Bratislava 1, Slovakia \\ e-mail: ${ }^{1}$ tatiana.pindjakova@stuba.sk, ${ }^{2}$ stanislav.kelcik@stuba.sk, \\ 3 andrej.soltesz@stuba.sk
}

Received 20 January 2015; accepted 22 June 2015

\begin{abstract}
The Slovak lowlands have been threatened by floods recently. The Levice district is one of the regions endangered by floods from extreme hydrological situations. The investigated river, which passes through this district is the River Podluzianka with the Cajkovsky brook and the Rybnicky brook as right-bank tributaries. The present conditions of the flood protection in the Levice district area are not sufficient. For this reason, it was necessary to analyze the river flow regime and propose appropriate flood protection measures in the mentioned region. This evaluation based on hydrological, geological and meteorological information and was performed by numerical modeling using computer code HEC-RAS. The main results of this research are presented in the paper.
\end{abstract}

Keywords: Hydraulic simulation, Detention reservoirs, Flood protection

\section{Introduction}

Flood protection measures are very important before flooding occurs. It is not possible completely avoid the formation of floods thus far, but it is possible to mitigate the final destructive effects on a population and its property. The Slovak Flood Protection Directive No. 7/2010 defines a flood as 'a temporary covering area, which is not normally covered by water' and also as 'a temporary significant water level increment where an imminent danger of spilling water appears' [1].

This article deals with the problems of the Levice district's flood protection including assessment and design measures on the River Podluzianka, which has the Cajkovsky and Rybnicky brooks as two tributaries. Generally, the flood protection here 
can be defined as an effort to create conditions in which the capacity of the River Podluzianka does not exceed $45 \mathrm{~m}^{3} \cdot \mathrm{s}^{-1}$ [2]. In the absence of protective measures in this region, flood discharges will surely exceed this limit, and they will still cause massive damage to urban and private property as they have previously done. Detailed research on the terrain of the individual sites suitable for the implementation of the flood protection measures has been carried out.

\section{Present situation}

The River Podluzianka is a stream with unstable discharges, which can run in a huge range. During a dry period the discharges here are just a few liters, but it can increase rapidly to several tens of cubic meters per second when a local storm situation occurs. This kind of discharge instability is a complicating factor in the design of flood protection measures. The character of the river adjustments, which have been realized here is just partial. These adjustments in relation to the flood protection measures at this area of interest are not sufficient. Based on the above fact it is necessary to deal with this problem. The channel of the River Podluzianka (and also its tributaries) has been adjusted to a 10-year discharge, which is not at all sufficient. Higher flow rates are spilling out and overflowing the area near the streams. When a hundred-year discharge flows there $\left(\mathrm{Q}_{100}=65 \mathrm{~m}^{3} \cdot \mathrm{s}^{-1}\right)$, two-third of this discharge flows outside the river beds and is parallel with the streams on the nearly flat river basin with a width of several tens to hundreds of meters. This water is only partially directed by the road and rail embankments, which have been built in this area. The River Podluzianka flows through Levice and its river bed in this part has been adjusted. In 2004, these adjustments were fully fulfilled with water at a length of 1250 meters. 'The research on runoffs in relation to the flood protection area' final report notes that it is extremely important to determine the flood discharges in the district of Levice. The difference between the water level during a flood and the capacity of a river bed increased by protective walls was calculated according to the present situation to reduce a 100 -year discharge $\left(65 \mathrm{~m}^{3} \cdot \mathrm{s}^{-1}\right)$ down to $45 \mathrm{~m}^{3} \cdot \mathrm{s}^{-1}$ in front of the town of Levice [3].

The uncontrollable over-spilling of flood discharges on the River Podluzianka also threatens the village of Podluzany (Fig. 1). The most critical section here is mainly above the road bridge in the village of Podluzany on the right-hand side.

\section{Flood protection measures in the district of Levice}

The River Podluzianka with its discharges and river basin area belongs among midsized rivers. The value of $\mathrm{Q}_{100}$ is $65 \mathrm{~m}^{3} . \mathrm{s}^{-1}$ and the flood protection measures were designed and realized only for $45 \mathrm{~m}^{3} \cdot \mathrm{s}^{-1}$. For the sufficient protection of the town these kinds of measures are is necessary:

- to increase the capacity of the river channel;

- to remove obstacles from the river channel;

- $\quad$ to adjust the river banks;

- to intercept any flood discharges in detention reservoirs. 


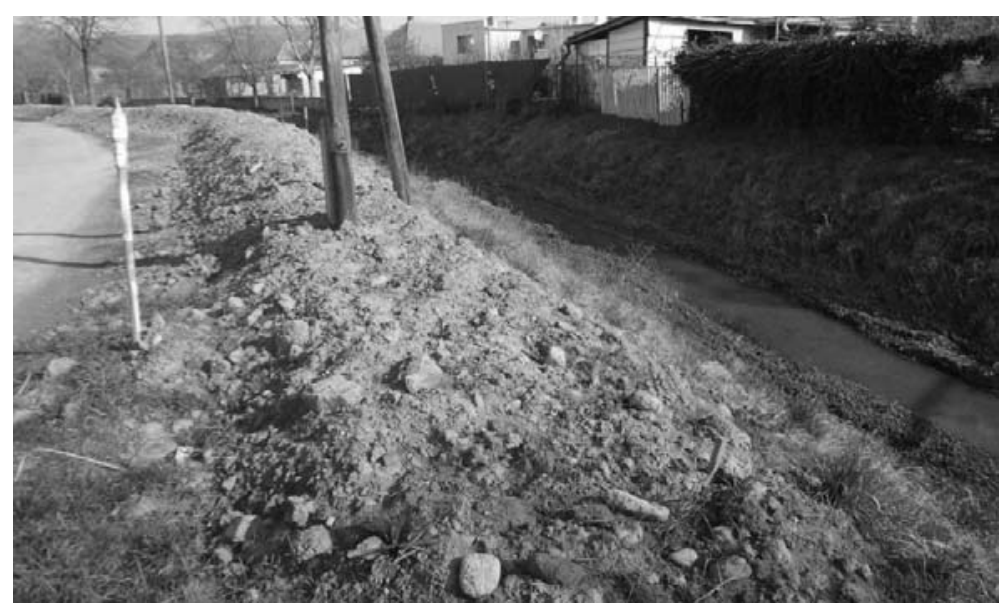

Fig. 1. The River Podluzianka in the village of Podluzany (photo Pindjaková)

The research on the terrain was realized in an area suitable for confining a flood to the detention reservoirs. Considering the fact that for the hydraulic calculations, the capacity of the river channels under the designed detention reservoirs was necessary to know the capacity the River Podluzianka's river bed. The Slovak Hydro-Meteorological Institute (SHMI) [4] provided the designed flood waves for the research. The data obtained was used for calculating the flattering of the flood waves. The calculations were realized in 7 defined areas (Fig. 2) from the data provided by The Slovak Water Board and from the terrain measurements.

Based on this information it was entered:

The volume of the detention reservoirs in the ArcGis software [5]; afterwards, the flood area and volume curves for calculating the river beds capacity below the designed detention reservoirs was evaluated. A methodology for calculating the hydraulic design of the detention reservoirs and constructed flattened flood waves from the designed flood waves, which were obtained from SHMI was created.

Within the scope of the article, it will be mentioned, as an example, the design of detention reservoir No. 1 at the River Podluzianka in $12.6 \mathrm{rkm}$.

\section{Hydraulic calculation of the detention reservoir No. 1}

For the hydraulic calculations of detention reservoir No. 1 at the River Podluzianka (12.6 rkm), the following assumptions were used:

- The design flood waves from the SHMI;

- The geodetic measurements of the areas upstream of the detention reservoir profiles; 
- The morphological limit of the height of the detention reservoirs (the state road);

- The river bed capacity of the River Podluzianka (which was evaluated in the Flowmaster software [6]) below the detention reservoir's profile.

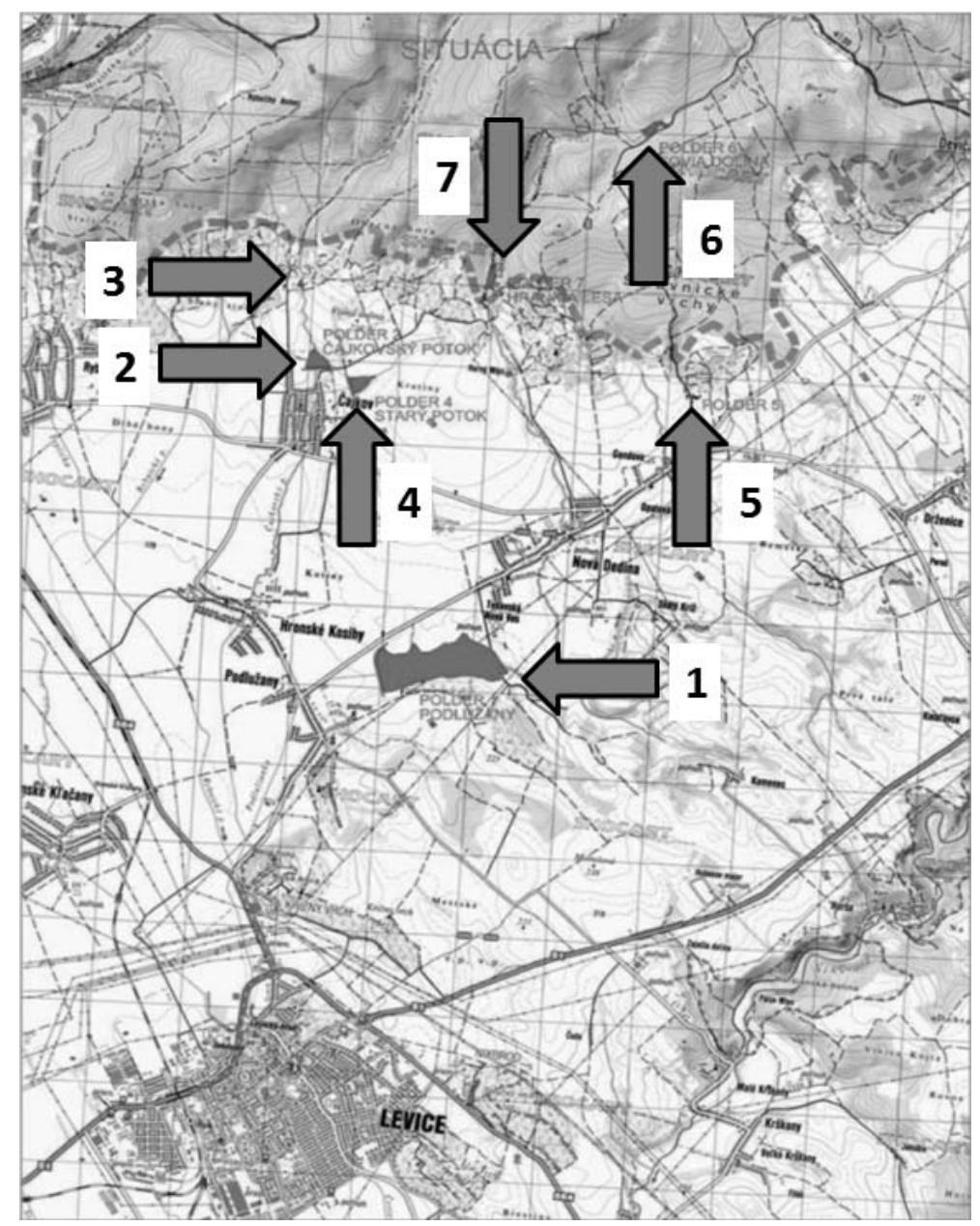

Fig. 2. Situation of the location of the designed detention reservoirs [7]

The hydraulic calculations were based on the following water balance equation:

$\left(Q_{p}-Q_{0}\right) \Delta t= \pm V$

where $Q_{p}$ is an inflow to the detention reservoir $\left[\mathrm{m}^{3} . \mathrm{s}^{-1}\right] ; Q_{0}$ is an outflow from the detention reservoir $\left[\mathrm{m}^{3} . \mathrm{s}^{-1}\right] ; \Delta \mathrm{t}$ is the time; and $V$ is the volume of water in the detention 
reservoir $\left[\mathrm{m}^{3}\right]$. Based on the solution of this equation, the height of the water level and also the depth of the culvert under the water level were set. The culvert was designed for flattening the designed flood wave from $45 \mathrm{~m}^{3} . \mathrm{s}^{-1}$ to a harmless discharge in the river bed below the detention reservoir's profile. According to the river bed's capacity measurements, the harmless discharge was determined to be not more than $24 \mathrm{~m}^{3} . \mathrm{s}^{-1}$. The shape of the designed flood wave is shown in Fig. 3.

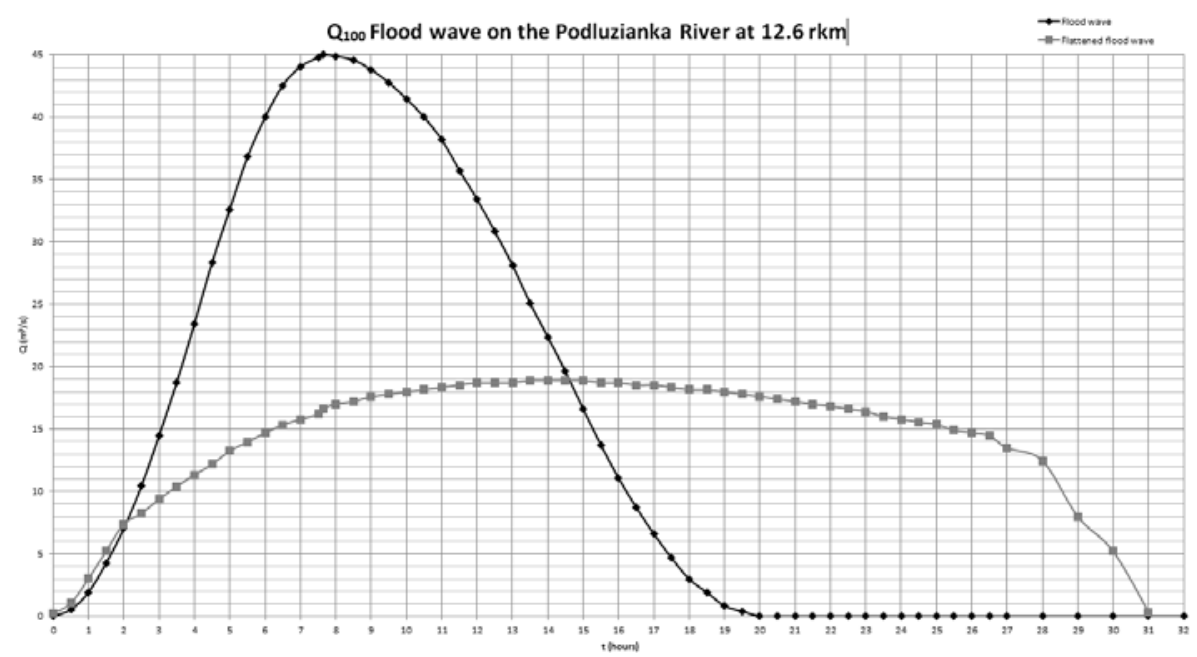

Fig. 3. Progress of flattening the flood wave by detention reservoir No. 1

The parameters that resulted from the hydraulic calculations and their graphic representation are as follows:

The height of the detention reservoir dam is 4.54 meters;

- The maximum outflow from the detention reservoir via a culvert (with 2 x $1.6 \mathrm{~m}$ dimensions) is $22.98 \mathrm{~m}^{3} \cdot \mathrm{s}^{-1}$;

- The designed flood wave of $45 \mathrm{~m}^{3} . \mathrm{s}^{-1}$ was flattened to a harmless discharge downstream of the detention reservoir;

- The calculated volume of the detention reservoir that would guarantee the accumulation of at $1.6 \mathrm{mil} . \mathrm{m}^{3}$ flood wave volume with a reduction of the discharge to a harmless $\mathrm{Q}=22.98 \mathrm{~m}^{3} . \mathrm{s}^{-1}$ was $670500 \mathrm{~m}^{3}$.

\section{Verification of the hydraulic calculations}

Based on the hydraulic calculations as the most effective solution the detention reservoir No. 1, as well as detention reservoirs No. 2 and No. 7 not included in this article (Fig. 2) were evaluated. A hydraulic model using the cross sections provided by The Slovak Water Boards [8] was created in the HEC-RAS Programme [9]. After the formation of the morphological model, the conditions for an unsteady flow using the 
designed flood waves were set. An unsteady flow simulation to verify the water volume accumulation necessary was used.

\section{Detention reservoir No. 1 on the River Podluzianka}

The height of the detention reservoir (Fig. 4) dam was raised by $0.5 \mathrm{~m}$; otherwise it would have continued to overflow $\left(Q_{0}=6.31 \mathrm{~m}^{3} \cdot \mathrm{s}^{-1}\right)$ the safety spillway $(20 \mathrm{~m}$ width and $0.37 \mathrm{~m}$ height of the overflowing water). In the next simulation the height of this dam by $0.5 \mathrm{~m}$ was raised; there was no spillway overflow and the detention reservoir was able to accumulate a volume of $760000 \mathrm{~m}^{3}$, which is about $160000 \mathrm{~m}^{3}$ more than at the height of 4.45 meters.

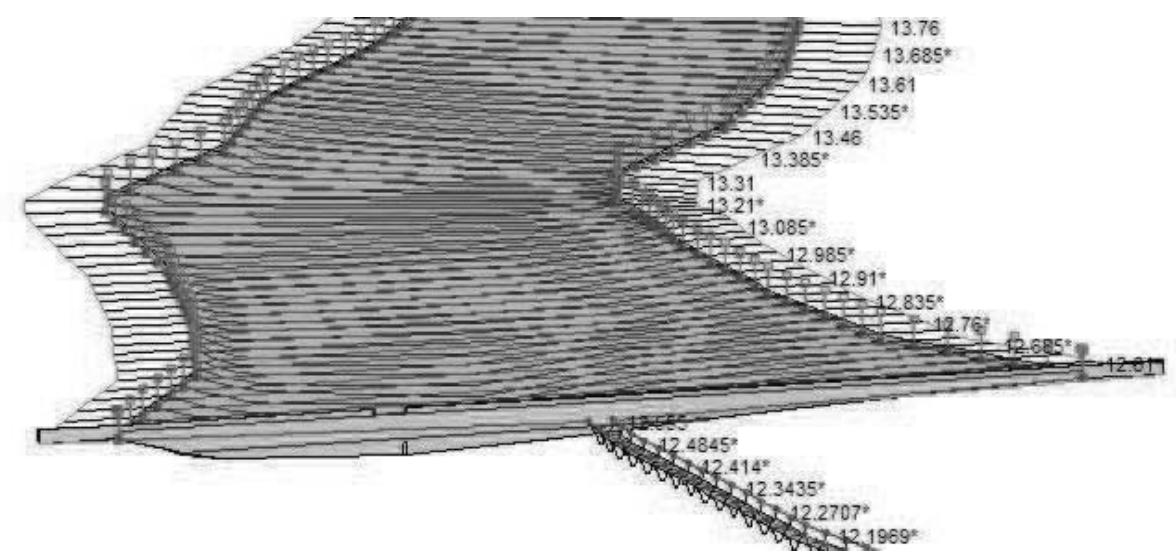

Fig. 4. Graphic presentation of the detention reservoir No. 1 at the maximum water level [8]

\section{Conclusion}

The water regime of the district of the town of Levice was analyzed according to the background materials from The SHMI as well as The Slovak Water Board and field research. It was determined that the flood protection measures in this area of interest are not sufficient. For the sufficient protection of the town it is necessary to ensure an increase in the river bed's capacity, to remove obstacles from the river bed, to adjust the river banks and to accumulate flood volumes in detention reservoirs. This article dealt with designing the flood protection measures in the area of the town Levice, specifically by catching flood wave volumes in the detention reservoirs. The designs of the detention reservoir No. 1 on the River Podluzianka and its hydraulic calculations have been explained in a more detailed way. The culvert was designed for flattening the designed flood wave from $45 \mathrm{~m}^{3} \cdot \mathrm{s}^{-1}$ to a harmless discharge in the channel below the detention reservoir profile. According to the capacity measurement, this discharge was set to be not more than $24 \mathrm{~m}^{3} \cdot \mathrm{s}^{-1}$. The hydraulic calculations were carried out by the HEC-RAS numerical modeling software. According to the modeling results, after raising the dam's height, there was no spillway overflow, and the detention reservoir 
could accept $760000 \mathrm{~m}^{3}$, which is about $160000 \mathrm{~m}^{3}$ more than it was before. The proposed flood protection measures could ensure the sufficient protection of the district town of Levice against floods within the $Q_{100}=65 \mathrm{~m}^{3} \cdot \mathrm{s}^{-1}$.

\section{References}

[1] Flood Protection Directive, No. 2007/60/EC.

[2] The Slovak Water Board, Flood protection measures in the Levice district, Environmental Impact Assessment Report, 2007.

[3] Water Research Institute, Research of impact of anthropogenic factors on water systems with respect to flood protection, 2002.

[4] Data obtained from The Slovak Hydro-Meteorological Institute, 2014.

[5] ArcGis Software Programme Handbook, Esri Press, 2011.

[6] Flowmaster Software, Hydraulic analysis and design software for open channels, pipes, weirs, and orifices, Haestead Methods, 1997.

[7] Šoltész A., Bednárová E., Minárik M., Gramblička M., Brček M., Kelčík S., Pindjaková T., Valachovič I. Podlužany-Gondovo, Flood protection measures in the catchment of the River Podluziankyr, Research Report, Slovak University of Technology in Bratislava, 2014.

[8] The Slovak Water Board, Data for design of flood protection measures on the River Podluzianka, Internal Report, 2013.

[9] HEC-RAS Programme, Hydrologic Engineering Centre, River analysis system, US Army Corps of Engineers, 2008. 